\title{
NOTE
}

\section{The red-tide dinoflagellate Heterocapsa sp. kills Gyrodinium instriatum by cell contact}

\author{
Takuji Uchida, Mineo Yamaguchi, Yukihiko Matsuyama, Tsuneo Honjo \\ Red Tide Research Division, Nansei National Fisheries Research Institute, Ohno, Saeki, Hiroshima 739-04, Japan
}

\begin{abstract}
The effects of the red-tide dinoflagellate Heterocapsa sp. on Gyrodinium instriatum were studied using laboratory cultures. Growth of $G$. instriatum was strongly suppressed when cultured together with Heterocapsa sp. Microscopical observations revealed that $G$. instriatum cells were immabilized by cell contact with Heterocapsa sp. The time necessary for the immobilization of $G$. instriatum cells decreased with increasing cell densities of Heterocapsa sp., which was related to the increasing chance of contact between the 2 organisms. Immobilized $G$. instriatum cells became abnormal in shape and finally lysed. H. triquetra had no effect on the motility of $G$. instriatum. This is the first report of inhibition of phytoplankton growth by cell contact.
\end{abstract}

KEY WORDS: Killer phytoplankton - Heterocapsa sp. C Cell contact Imrnobilization - Growth inhibition - Gyrodinium instriatum

Red tides of the dinoflagellate Heterocapsa sp. caused heavy damages to bivalves in the inner bays of Japan (Yamamoto \& Tanaka 1990, Y. Matsuyama et al. unpubl.). The bloom of this species occurred from August to December in Ago Bay. It developed to red tides in summer and autumn, with a maximum cell density of more than 80000 cells $\mathrm{ml}^{-1}$ in August (Matsuyama et al. unpubl.). Ecological and physiological studies have been conducted to elucidate the cause and mechanism of red tides of this species. In the course of investigating the relation between Heterocapsa sp. and other flagellates, it was found that Heterocapsa sp. immobilized cells of Gyrodinium instriatum by cell contact, resulting in the death of the $G$. instriatum cells. There have been many reports on interactions between phytoplankton species being mediated by chemical compounds secreted into the environment (Maestrini \& Bonin 1981, Rice 1984) and on grazerprey relationships such as phagotrophy, myzocytosis and pallium feeding (Elbrächter 1991). We report here a new type of inhibition involving Heterocapsa sp. and G. instriatum.

Materials and methods. The strains of Gyrodinium instriatum Freudenthal et Lee (Fig. 1A), Heterocapsa sp. (Fig. 1D), and $H$. triquetra (Ehrenberg) Stein used in these experiments were isolated from seawater samples collected from Uranouchi Bay in April 1993, from Ago Bay in December 1992, and from Hiroshima Bay in April 1991, respectively. A morphological study of Heterocapsa sp. has been made for the cultured materials. This

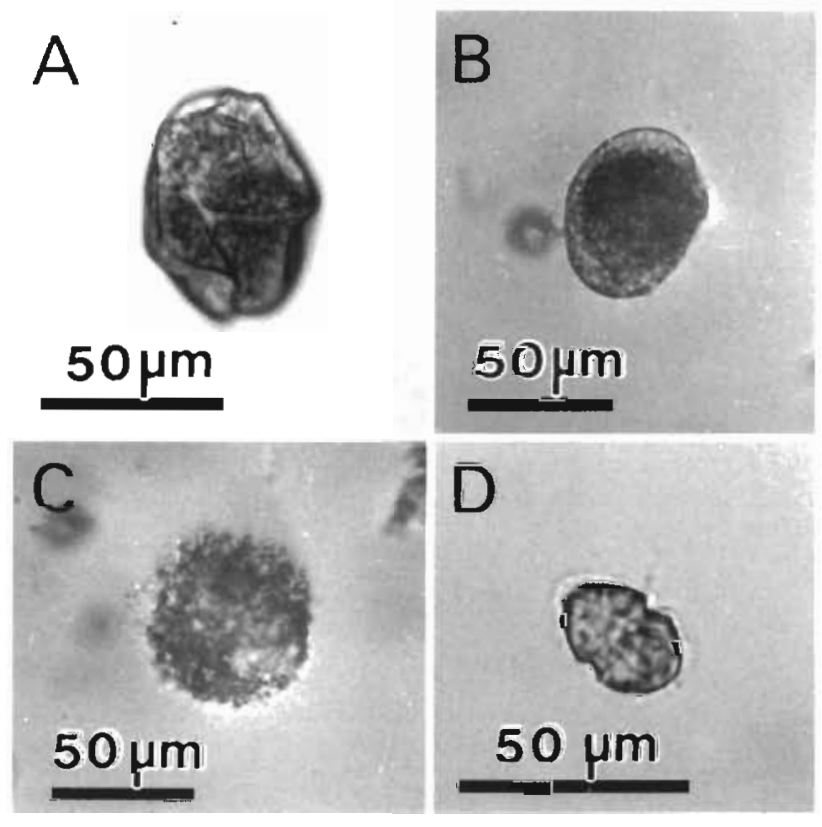

Fig. 1. Photomicrographs of Gyrodinium instriatum and Heterocapsa sp. (A) Normal motile cell of $G$. instriatum. (B) Cell of $G$. instriatum immobilized by Heterocapsa sp. The cell became elliptical and lost flagella, girdle, and sulcus. (C) G. instriatum cell lysed as a result of contact with Heterocapsa sp. (D) Motile cell of Heterocapsa sp. (fixed with 1\% glutaraldehyde) 
species is light yellow-brown in color and spindle shaped. Cells have a typical dinoflagellate morphology with sulcal and girdle grooves. Cells are 18 to $30 \mu \mathrm{m}$ in length and 12 to $22 \mu \mathrm{m}$ in width. Epitheca is slightly pointed. According to T. Horiguchi (pers. comm.), the cells of Heterocapsasp. have scales on their surface, and this species is closely related to $H$. illdefina (= Cachonina illdefina) described by Herman \& Sweeney (1976) and Morrill \& Loeblich (1981). Further study is necessary to decide the taxonomical status of this species.

Clonal cultures of Gyrodinium instriatum, Heterocapsa sp. and $H$. triquetra were obtained by repeated washings using capillary pipettes. The cultures thus obtained were subjected to sterility tests using ST10-1 medium (Ishida et al. 1986). For each of the cultures, no bacterial growth was observed more than 1 mo after inoculation. Modified SWM-3 (Itoh \& Imai 1987) was used as a culture medium throughout the experiments. Growth experiments using bialgal cultures were conducted in $50 \mathrm{ml}$ Erlenmeyer flasks with $25 \mathrm{ml}$ of medium. Cells in the logarithmic phase of growth were inoculated at densities of about 100 cells $\mathrm{ml}^{-1}$ for $G$. instriatum and 200 to $300 \mathrm{cells} \mathrm{m}^{-1}$ for Heterocapsa sp. Cultures were maintained at $20^{\circ} \mathrm{C}$ on a $12 \mathrm{~h}$ light: $12 \mathrm{~h}$ dark cycle; illumination was provided by cool-white fluorescent lamps at 120 to $150 \mu \mathrm{mol}$ photon $\mathrm{m}^{-2} \mathrm{~s}^{-1}$. Growth was measured at 2 to 5 dintervals by counting cells in 0.01 to $0.1 \mathrm{ml}$ culture samples using a Sedgwick-Rafter slide. When cell densities were greater than 20000 cells $\mathrm{ml}^{-1}$, the samples were diluted 10 to 20 times with autoclaved seawater. The cell conditions of the 2 organisms in the bialgal cultures were observed using an inverted microscope. When necessary, $1 \mathrm{ml}$ of the culture was aseptically transferred to a well of a 24-well plate (Sumitomo Bakelite Co., Ltd) to undergo detailed microscopic observations.

Short-term effects of Heterocapsa sp. on the motility of Gyrodinium instriatum were studied at room temperature $\left(22\right.$ to $24^{\circ} \mathrm{C}$ ). A total of $0.5 \mathrm{ml}$ of Heterocapsa sp. culture (monoalgal) with 10000 to 50000 cells $\mathrm{ml}^{-1}$ were added to each well of a 24 -well plate. Three wells were used for each concentration of Heterocapsa sp. cells. Then, 20 cells of $G$. instriatum, in log-phase growth, were isolated by capillary pipette and inoculated into the wells. As controls, the Heterocapsa sp. culture was replaced either with filtrate from a Heterocapsa sp. culture or with fresh culture medium. Three wells were used for each control. The filtrate was prepared by mild filtration of the Heterocapsa sp. culture through membrane filters of $0.2 \mu \mathrm{m}$ pore size using disposable filter holders (Schleicher \& Schuell). Using an inverted microscope, the time course of the occurrence of immotile $G$. instriatum cells was followed immediately after inoculation. In a similar fashion, $H$. triquetra was tested for its ability to immobilize $G$. instriatum cells.

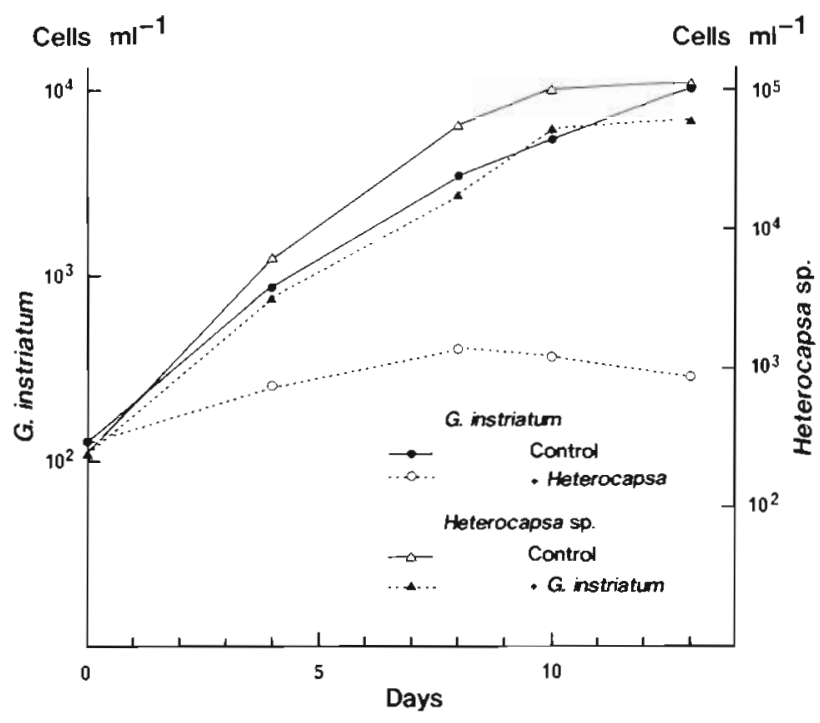

Fig. 2. Growth of Gyrodinium instriatum and Heterocapsa $\mathrm{sp}$. when cultured alone $(\bullet, \Delta$ respectively) or together $(0, \Delta$ respectively)

Results and discussion. Fig. 2 shows the growth of Gyrodinium instriatum and Heterocapsa sp. cultured alone or together. It is clear that the growth of $G$. instriatum was strongly suppressed when cultured with Heterocapsa sp. The growth of $G$. instriatum was very limited up to $8 \mathrm{~d}$ after inoculation, then cell densities decreased gradually, whereas the cells in the control continued to grow during the experiment. There was no such remarkable difference in growth of Heterocapsa sp. between bialgal and unialgal (control) cultures, although growth in the bialgal culture seemed to be slightly suppressed.

The condition of Gyrodinium instriatum and Heterocapsa sp. cells in the bialgal culture was observed using an inverted microscope. The observations indicated that $G$. instriatum cells became immotile immediately after contact with Heterocapsa sp. The immotile $G$. instriatum cells became elliptical and lost their flagella, girdles, and sulci (Fig. 1B) and finally lysed (Fig. 1C). In some cases, it was observed that immobilized $G$. instriatum cells recovered their motility. However, these cells soon became immotile again after repeated contact with Heterocapsa sp. Immobilization of $G$. instriatum cells did not always occur upon contact with Heterocapsa sp. Perhaps there is a specific region on $G$. instriatum cells that is sensitive to the attack of Heterocapsa sp. Finally, the motility of Heterocapsa sp. cells was not affected by contact with $G$. instriatum cells.

Fig. 3 shows the decrease in the number of motile cells of Gyrodinium instriatum at a density of 23400 cells ml $\mathrm{ml}^{-1}$ of Heterocapsa sp. Most $G$. instriatum 


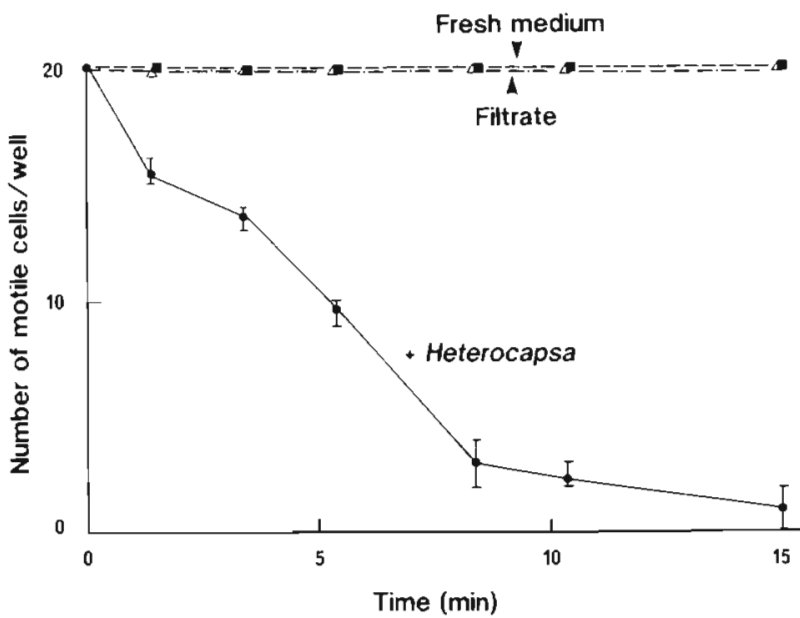

Fig. 3. Time course of the decrease in the number of motile cells of Gyrodinium instriatum upon exposure to Heterocapsa sp. at 23400 cells $\mathrm{ml}^{-1}$ Mean value ( $\bullet$ ) and the range (vertical bars) are shown for each measurement $(n=3)$. ( - Fresh medium; ( 8 ) filtrate

cells became immotile within 15 min. Immobilization was not observed in the fresh medium or the filtrate. The time necessary for immobilization of half of the $G$. instriatum cells ( 10 cells) was $15 \mathrm{~min}$ at a density of 10200 cells ml $\mathrm{m}^{-1}$ of Heterocapsa sp., $5 \mathrm{~min}$ at 23400 cells ml-1 and 2 min at 49000 cells ml ${ }^{-1}$. It is evident that the immobilization of $G$. instriatum was more rapid at higher cell densities of Heterocapsa sp. This is probably due to the fact that higher cell densities of Heterocapsa sp. increased the chance of contact between the 2 organisms. The ability of Heterocapsa sp. to immobilize G. instriatum cells did not change significantly during the experiments. The cells of Heterocapsa sp. used in the present experiments were the 50 th to 100 th generation after isolation from seawater (maintained for 6 to 10 mo in laboratory cultures).

Experiments were conducted to determine if Heterocapsa triquetra, a common species, produces a similar effect on Gyrodinium instriatum. Results indicate that the motility of $G$. instriatum was not affected by the presence of 90000 cells $\mathrm{ml}^{-1}$ of $H$. triquetra.

Allelopathy between phytoplankton species has been limited to cases mediated by chemical compounds secreted by certain species into the environment (Maestrini \& Bonin 1981, Rice 1984). In this context, the inhibitory effect of Heterocapsa sp. on Gyrodinium instriatum is noteworthy for 2 reasons. One is that the inhibition was realized by cell contact between the 2 organisms. The other is that the immobilization of $G$. instriatum occurred immediately after

This note was submitted to the editor the contact and finally resulted in the death of the cells. This type of inhibition has never been reported for phytoplankton species until now.

The mechanisms of immobilization are unknown. It is possible that an inhibitory substance was attached to the Gyrodinium instriatum cells by contact with Heterocapsa sp. Another possible explanation is that the cells of $G$. instriatum were damaged mechanically by contact with Heterocapsa sp. Perhaps Heterocapsa sp. has an unusual organelle that enables it to immobilize G. instriatum cells. If Heterocapsa sp. also immobilizes other phytoplankters, it may be a strategy for keeping itself dominant in the phytoplankton community. The newly found type of inhibition by Heterocapsa sp. revealed in the present study offers a unique phenomenon for further ecological and physiological studies.

Acknowledgements. We thank the members of the Fisheries Research Institute of Mie and the members of the Kochi Prefectural Fisheries Experimental Station for providing us seawater samples for the isolation of the phytoplankton species used in the experiments. We also thank Dr T Horiguchi of Hokkaido University for the identification of the genus of Heterocapsa sp. Thanks are due to Dr I. Imai of Kyoto University for comments on the experiments and to Dr T Kamiyama of the same institute for providing us with the culture of $H$. triquetra used in the experiments.

\section{LITERATURE CITED}

Elbrächter, M. (1991). Food uptake mechanisms in phagotrophic dinoflagellates and classification. In: Patterson, D. J., Larsen, J. (eds.) The biology of free-living heterotrophic flagellates. Systematics Association by Clarendon Press, Oxford, p. 303-312

Herman, E. M., Sweeney, B. M. (1976). Cachonina illdefina sp. Nov. (Dinophyceae): chloroplast tubules and degeneration of the pyrenoid. J. Phycol. 12: 198-205

Ishida, Y., Eguchi, M., Kadota, H. (1986). Existence of obligately oligotrophic bacteria as a dominant population in the South China Sea and the West Pacific Ocean. Mar. Ecol. Prog. Ser. 30: 197-203

Itoh, K., Imai, I. (1987). Rafido-So. In: The Japan Fisheries Resource Conservation Association (ed.) A guide for studies of red tide organisms. Shuwa, Tokyo, p. 122-130 (in Japanese)

Maestrini, S. Y., Bonin, D. J. (1981). Allelopathic relationships between phytoplankton species. In: Platt, T. (ed.) Physiological bases of phytoplankton ecology. Can. Bull. Fish. Aquat. Sci. 210: 323-338

Morrill, L. C., Loeblich, A. R. III (1981). A survey for body scales in dinoflagellates and a revision of Cachonina and Heterocapsa (Pyrrophyta). J. Plankton Res. 3: 53-65

Rice, E. L. (1984). Allelopathy. Academic Press, London

Yamamoto, C. Tanaka, Y (1990). Two species of harmful red tide plankton increased in Fukuoka Bay. Bull. Fukuoka Fish. Exp. Stn. 16: 43-44 (in Japanese)

Manuscript first received: July 18, 1994

Revised version accepted: November 11, 1994 